\title{
PREVALENSI EKTOPARASIT PADA IKAN BUDIDAYA DI KARAMBA JARING APUNG DI TELUK KAPING, BULELENG, BALI
}

\author{
Zafran $^{\mathrm{a}, *}$, Des Roza ${ }^{\mathrm{a}}$, dan Ketut Mahardika \\ ${ }^{a}$ Balai Besar Riset Budidaya Laut dan Penyuluhan Perikanan, Gondol, Bali, Indonesia \\ *Koresponden penulis : Zafran16@yahoo.com
}

\begin{abstract}
Abstrak
Perairan laut Buleleng Utara merupakan salah satu sentra pengembangan budidaya perikanan laut di Propinsi Bali. Salah satu kendala dalam pengembangan budidaya laut adalah terjadinya kematian ikan budidaya yang antara lain disebabkan oleh serangan parasit. Penelitian ini bertujuan untuk mengetahui jenis ektoparasit yang menginfeksi ikan yang dibudidayakan di karamba jaring apung (KJA) serta tingkat prevalensinya. Penelitian dilakukan selama lima bulan dengan cara mengambil masing-masing 10 ekor sampel ikan dari tiga KJA berbeda yang berlokasi di Teluk Kaping, Kecamatan Gerokgak, Buleleng, Bali. Sampel ikan dalam keadaan hidup yang diambil setiap bulan selanjutnya dibawa ke laboratorium Patologi Balai Besar Riset Budidaya laut dan Penyuluhan Perikanan, Gondol, Bali. Pengamatan morfologi parasit dilakukan secara mikroskopis terhadap preparat insang dan lendir permukaan tubuh ikan. Hasil pengamatan menunjukkan bahwa parasit utama yang menginfeksi ikan adalah lintah Hirudinea (Zeylanicobdella arugamensis) dengan prevalensi mencapai $100 \%$ diikuti oleh Benedenia sp (40\%), Trichodina sp (33.33\%), cacing insang (33.33\%), Lepeophtheirus sp (26.67\%), dan Cryptocaryon irritans (13.33\%).
\end{abstract}

Kata Kunci: Ektoparasit, Karamba jaring apung, Teluk Kaping

\begin{abstract}
Northern coast of Buleleng is a potential area for marine aquaculture development in Bali Province. One of problems faced in development of mariculture is mortality due to diseases, including parasitic disease. The aims of this study were to identify of parasites and to determine the prevalence of each parasite on the fish cultured in floating net cages at Kaping Bay, Gerokgak, Buleleng. Identification based on morphology of parasites using fresh specimens. This study was conducted for five months. Ten fish each were collected randomly from 3 different floating cages every month. The fish then were transported in live condition to pathology laboratory of Institute for Mariculture Research and Fisheries Extension, Gondol. Small part of gill filaments and mucus from body surface were put on object glasses and then observed under light microscope. The result showed that the main parasite found were marine leech (Zeylanicobdella arugamensis) with prevalence reached $100 \%$ followed by skin fluke (Benedenia sp) with $40 \%$ prevalence, Trichodina sp (33.33\%), gill fluke (33.33\%), Lepeophtheirus sp (26.67\%), and Cryptocaryon irritans (13.33\%), respectively.
\end{abstract}

Keywords: Ectoparasite, Floating net cage, Kaping Bay

\section{PENDAHULUAN}

Budidaya perikanan laut di Indonesia merupakan salah industri yang mengalami peningkatan secara pesat sejak beberapa tahun belakangan karena permintaan pasar yang tinggi. Kecamatan Gerokgak, Kabupaten Buleleng, Bali, telah dikenal sebagai sentra budidaya bandeng dan kerapu terbesar di Indonesia. Luas lahan potensial untuk budidaya laut di Kabupaten Buleleng diperkirakan \pm 1.050 Ha. Lokasi yang berpotensi untuk budidaya laut adalah di sepanjang pantai Kecamatan Gerokgak, dimana potensi yang sudah dimanfaatkan untuk budidaya laut yaitu seluas $151,15 \mathrm{Ha}$ atau $14,39 \%$. Salah satu komoditas yang dikembangkan adalah ikan kerapu dengan luas 48,2 Ha, dan di tahun 2016 telah berproduksi sebesar 190,5 ton. Sedangkan produksi ikan kerapu dari KJA sebanyak 47 ton, serta ikan kakap sebesar 652,6 ton [1].

Perkembangan budidaya perikanan ini, belakangan telah dirasakan adanya penurunan produksi baik yang disebabkan oleh sering terjadinya penyakit infeksi yang berakibat 
pada kematian massal. Perubahan iklim yang terjadi belakangan ini berupa fluktuasi suhu perairan sangat signifikan mempengaruhi tingkat produktivitas budidaya laut yang terjadi di Teluk Pegametan dan teluk Penerusan. Penurunan suhu juga telah mempengaruhi tingkat kematian ikan budidaya terutama jenis ikan kerapu [2], [3]. Kerusakan lingkungan perairan akibat aktivitas budidaya telah dilaporkan di beberapa tempat di berbagai negara [4], [5]. Pada kegiatan budidaya, penggunaan pakan buatan dan pupuk pada plankton serta sisa bahan organik dari bak-bak pemeliharaan induk/larva ikan merupakan sumber utama pencemaran ke perairan sekitarnya. Sisa bahan organik dari sistem budidaya yang berlangsung terus menerus akan menyebabkan akumulasi dan meningkatkan proses dekomposisi di dasar perairan menjadi senyawa terlarut, sehingga akan menurunkan kualitas perairan, menjadi racun bagi sebagian organisme perairan, sebagai penyebab dari blooming plankton tertentu dan pada akhirnya merusak ekosistem perairan setempat [6], [7], [8]. Perubahan lingkungan perairan juga berdampak pada kesehatan ikan. Beberapa patogen seperti cacing insang dan lintah Hirudinea dilaporkan menyebabkan kematian massal pada ikan kerapu di Teluk Pegametan [9].

Tujuan dari penelitian ini adalah untuk mengetahui jenis parasit serta tingkat prevalensinya pada ikan laut yang dibudidayakan di Teluk Kaping, Kecamatan Gerokgak, Buleleng. Penelitian ini diperlukan untuk bisa menentukan upaya pengendalian penyakit parasitik secara tepat di KJA.

\section{METODE PENELITIAN}

\section{Waktu dan lokasi penelitian}

Penelitian dilakukan selama lima bulan dari Bulan Februari sampai Juni 2018 di sentra pembesaran ikan kerapu di keramba jaring apung di Teluk Kaping, Desa Sumberkima, Kecamatan Gerokgak, Kabupaten Buleleng, Bali. Sampling dilakukan dengan mengambil sampel ikan masing-masing sebanyak 10 ekor secara acak dari tiga KJA setiap bulannya. Ikan sampel selanjutnya dibawa dalam keadaan hidup ke Laboratorium Patologi BBRBLPP, Gondol, Bali untuk pengamatan selanjutnya.

\section{Pengamatan parasit}

Sebagian kecil dari lamella insang (sebelah kiri dan kanan) ikan sampel dipotong dengan gunting dan ditempatkan pada gelas objek dan selanjutnya diamati secara mikroskopis. Pengamatan keberadaan parasit juga dilakukan terhadap lendir permukaan tubuh ikan sampel. Jenis parasit diidentifikasi secara morfologi, yaitu dengan melihat struktur, bentuk, dan bagian dari tubuh luar, berpedoman pada beberapa referensi [10][14]. Prevalensi dihitung dengan rumus: $\mathrm{P}=$ $\mathrm{N} / \mathrm{n} \times 100 \%$, dimana $\mathrm{P}=$ prevalensi, $\mathrm{N}=$ jumlah ikan yang terinfeksi, dan $n=$ jumlah ikan yang diamati.

\section{HASIL DAN PEMBAHASAN}

Pada sampling Bulan Februari terpantau ada beberapa jenis parasit pada insang, yaitu Trichodina, Benedenia, dan cacing insang, dengan tingkat prevalensi rendah. Pada kulit ditemukan Benedenia dan Hirudinea. Infeksi Hirudinea memiliki tingkat prevalensi paling tinggi, yaitu $80 \%$ (Tabel 1).

Tabel 1. Jenis dan prevalensi parasit yang ditemukan pada Bulan Februari

\begin{tabular}{|c|c|c|c|}
\hline KJA & $\begin{array}{c}\text { Ikan } \\
\text { Sampel }\end{array}$ & Jenis Parasit & Prevalensi \\
\hline \multirow[t]{5}{*}{ KJA-1 } & Kerapu & Pada Insang: & \\
\hline & Cantik & Trichodina & $10 \%$ \\
\hline & & Gill fluke & $10 \%$ \\
\hline & & Pada Kulit: & \\
\hline & & $\overline{\text { Benedenia }}$ & $40 \%$ \\
\hline \multirow[t]{6}{*}{ KJA-2 } & Kerapu & Pada Insang: & \\
\hline & Cantik & Benedenia & $10 \%$ \\
\hline & & Trichodina & $10 \%$ \\
\hline & & Gill fluke & $10 \%$ \\
\hline & & Pada Kulit: & \\
\hline & & $\overline{\text { Benedenia }}$ & $40 \%$ \\
\hline \multirow[t]{7}{*}{ KJA-3 } & Kerapu & Pada Insang: & \\
\hline & Cantik & Trichodina & $40 \%$ \\
\hline & & Gill fluke & $10 \%$ \\
\hline & & Pada Kulit: & \\
\hline & & $\overline{\text { Benedenia }}$ & $40 \%$ \\
\hline & & Gill fluke & $10 \%$ \\
\hline & & Hirudinea & $80 \%$ \\
\hline
\end{tabular}


Dari hasil sampling pada bulan Maret terhadap ikan kerapu cantang dan kerapu cantik, parasit yang terdeteksi pada insang adalah Lepeophtheirus, cacing insang, dan Hirudinea. Pada lendir kulit ditemukan Hirudinea dan Benedenia. Hirudinea ditemukan dengan tingkat prevalensi yang tinggi, sampai 100\% (Tabel 2). Satu ekor ikan bahkan ditempeli lebih dari 100 individu lintah Hirudinea (Gambar 1). Parasit Hirudinea mudah diamati secara kasat mata karena ukurannya lumayan besar, bisa sampai $20 \mathrm{~mm}$ pada stadia dewasa. Parasit ini menyerang pada bagian mulut, mata, permukaan kulit badan, tutup insang, dan sirip. Hirudinea menempel pada inangnya menggunakan sucker yang berfungsi untuk menghisap darah inangnya sebagai sumber nutrisinya. Pada tingkat infeksi parah, ikan terlihat lemah dan kurus.

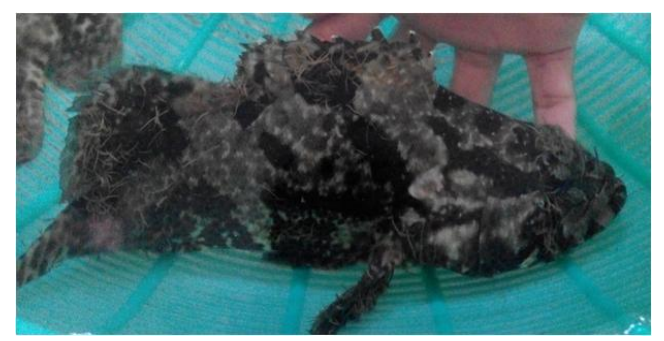

Gambar 1. Hirudinea pada ikan kerapu

Hirudinea memiliki bentuk silinder, lunak, elastis, permukaan tubuh yang halus, memiliki dua sucker, yaitu anterior sucker dan posterior sucker dimana posterior sucker memiliki ukuran lebih besar daripada anterior sucker. Pada anterior sucker terdapat sepasang bintik mata. Parasit ini juga memiliki 12 ruas (segmen), 5 pasang testis, dan sepasang ovary. Berdasarkan morfologi ini dan dicocokkan dengan kunci determinasi [10] maka parasit ini diidentifikasi sebagai Zeylanicobdella arugamensis. Sebelumnya, Hirudinea yang menginfeksi ikan kerapu di KJA Teluk Pegametan, Gerokgak, Bali, secara molekuler telah diidentifikasi sebagai Zeylanicobdella arugamensis [15]. Infeksi ikan budidaya oleh parasit Hirudinea di kawasan Asia Tenggara pertama kali dilaporkan pada ikan kerapu malabar (Epinephelus malabaricus) di Malaysia tapi belum teridentifikasi secara ilmiah [16]. Parasit yang sama selanjutnya dilaporkan di Filipina pada ikan kerapu lumpur (Epinephelus coioides) dan diidentifikasi sebagai Zeylanicobdella arugamensis [17].

Infeksi Hirudinea pada ikan di KJA lebih sulit diatasi dibandingkan dengan di hatchery. Kalau di hatchery bisa dilakukan pengobatan dan karantina terhadap ikan sakit secara terpisah. Selain itu wadah pemeliharaan ikan juga bisa didesinfeksi untuk memutus siklus hidup dari parasit tersebut. Tapi di KJA hal yang sama tidak bisa diterapkan. Telur-telur dari Hirudinea bisa menempel pada berbagai benda padat yang ada di lingkungan KJA dan bisa menetas setiap saat. Walaupun ikan yang terinfeksi Hirudinea bisa diobati tapi begitu dimasukkan lagi ke dalam KJA maka mereka akan terinfeksi lagi. Selain itu padatnya KJA dalam satu kawasan juga memudahkan parasit Hirudinea menular dari satu KJA ke KJA lainnya. Siklus hidup Hirudinea untuk daerah tropis ternyata juga cukup singkat dimana dari telur menetas sampai stadia dewas dan menghasilkan telur lagi hanya butuh waktu 21 hari pada suhu $24-25^{\circ} \mathrm{C}$ dan salinitas $34 \mathrm{ppt}$ [15]. Pada suhu $27^{\circ} \mathrm{C}$ dan salinitas $28 \mathrm{ppt}$ ternyata siklus hidup lengkap dari $Z$. arugamensis hanya butuh waktu 16-17 hari [18].

Lepeophtheirus adalah parasit dari jenis kopepoda (krustase). Selama ini belum ada laporan infeksi Lepeophtheirus bisa mematikan ikan inang secara langsung. Pada infeksi berat parasit ini menyebabkan kerusakan kulit dan otot ikan inangnya sehingga bisa menjadi pintu masuk bagi infeksi sekunder seperti infeksi bakteri misalnya. Infeksi sekunder inilah yang bisa menyebabkan kematian bagi ikan inang.

Secara morfologi parasit ini mempunyai kemiripan dengan Caligus. Bedanya adalah Lepeophtheirus tidak mempunyai sepasang lunulus pada ujung anteriornya sebagaimana pada Caligus (Gambar 2). Parasit ini sebelumnya telah dilaporkan menginfeksi ikan kerapu malabar, kerapu lumpur, dan kerapu macan [13]. Pada penelitian ini parasit yang sama ditemukan juga pada kerapu cantang dan cantik dengan tingkat prevalensi mencapai $40 \%$. Tapi dari 5 bulan pemantauan parasit, 
infeksi Lepeophtheirus hanya terdeteksi satu kali, yaitu pada bulan Maret. Karena itu parasit Lepeophtheirus bukanlah parasit yang dapat mengancam budidaya ikan laut di KJA.

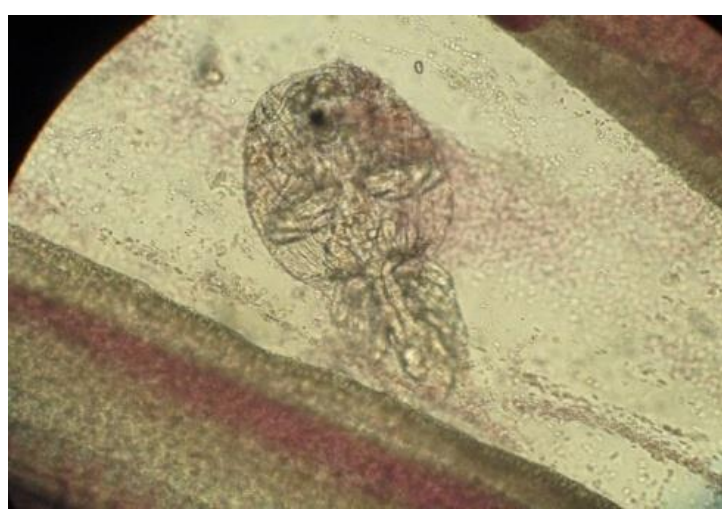

Gambar 2. Parasit Lepeophtheirus

Tabel 2. Jenis dan prevalensi parasit yang ditemukan pada Bulan Maret

\begin{tabular}{cllc}
\hline KJA & $\begin{array}{c}\text { Ikan } \\
\text { Sampel }\end{array}$ & Jenis Parasit & Prevalensi \\
\hline KJA-1 & $\begin{array}{l}\text { Kerapu } \\
\text { Cantang } \\
\\
\text { dan }\end{array}$ & $\begin{array}{l}\text { Pada Insang: } \\
\text { Lepeophtheirus }\end{array}$ & $10 \%$ \\
& Cantik & Hirudinea & $100 \%$ \\
KJA-2 & Kerapu & Pada Insang: & \\
& Cantik & Lepeophtheirus & $30 \%$ \\
& & Gill fluke & $10 \%$ \\
& & Pada Kulit: & \\
& & Hirudinea & $70 \%$ \\
KJA-3 & Kerapu & Pada Insang: & \\
& Cantik & Lepeophtheirus & $40 \%$ \\
& & Gill fluke & $20 \%$ \\
& & Hirudinea & $20 \%$ \\
& & Pada Kulit: & \\
& & Benedenia & $40 \%$ \\
& & Hirudinea & $100 \%$ \\
\hline
\end{tabular}

Pada sampling bulan April, pada insang ikan kerapu cantik ditemukan adanya parasit Cacing insang, Benedenia dan Trichodina, tapi dengan tingkat prevalensi yang rendah. Sebaliknya pada lendir kulit ditemukan parasit Hirudinea dengan tingkat prevalensi tinggi, mencapai 100\% (Tabel 3).

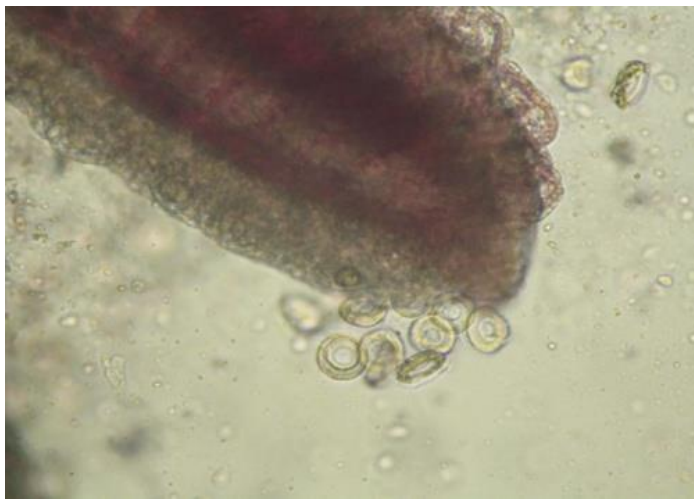

Gambar 3. Trichodina pada insang

Trichodina (Protozoa; Ciliata) adalah parasit yang tidak mempunyai inang yang spesifik, umum ditemukan menyerang berbagai spesies ikan laut maupun ikan air tawar. Dari sekian banyak parasit dari kelompok Protozoa, Trichodina (Gambar 3) termasuk sebagai salah satu parasit yang berbahaya pada ikan laut budidaya [19]. Parasit dari kelompok Trichodinid menginfeksi ikan dari semua kelompok umur tetapi umumnya lebih banyak pada benih maupun fingerling [11]. Parasit ini mempunyai bentuk seperti cawan dengan diameter berkisar dari $45-78 \mu \mathrm{m}$ dan dilengkapi bulu getar (cilia) pada tepi tubuhnya. Sebelumnya parasit ini juga ditemukan pada ikan kerapu macan (Epinehelus fuscoguttatus) dan kakap putih (Lates calcarifer). Dari Filipina, Trichodina dilaporkan juga menginfeksi Epinephelus bleekeri, E. bontoides, E. malabaricus, E. suillus, E. tauvina, dan Cromileptes altivelis [20]. Parasit Trichodina mampu menembus ke dalam lamella insang dan bahkan menembus ke dalam pembulu darah sehingga bisa menyebabkan pendarahan. Ikan yang terinfeksi Trichodina biasanya akan berenang lambat dekat permukaan air dan kehilangan nafsu makan.

Pada sampling bulan Mei, parasit yang ditemukan relatif sama dengan sampling pada bulan April, yaitu terdiri dari parasit Trichodina, Benedenia, cacing insang, dan Hirudinea, hanya terdapat perbedaan dalam prevalensinya saja. Cacing insang pada salah satu KJA (KJA 1) prevalensinya mencapai $100 \%$ (Tabel 4). Gejala klinis yang terlihat pada ikan sakit antara lain nafsu makan 
hilang, berenang abnormal (erratic swimming) pada permukaan air, warna tubuh pucat, filamen insang rusak sehingga pada tingkat parah dapat mengganggu proses respirasi ikan, dan insang terlihat pucat akibat anemia. Ada tiga jenis cacing insang yang umum ditemukan pada ikan sakit, yaitu Haliotrema, Pseudorhabdosynochus, dan Diplectanum [13].

Tabel 3. Jenis dan prevalensi parasit yang ditemukan pada Bulan April

\begin{tabular}{cclc}
\hline KJA & $\begin{array}{c}\text { Ikan } \\
\text { Sampel }\end{array}$ & Jenis Parasit & Prevalensi \\
\hline KJA-1 & Kerapu & Pada Insang: & - \\
& Cantik & - & \\
& & Pada Kulit: & \\
& & Hirudinea & $100 \%$ \\
KJA-2 & Kerapu & Pada Insang: & \\
& Cantik & - & - \\
& & Pada Kulit: & \\
& & Benedenia & $10 \%$ \\
& & Hirudinea & $100 \%$ \\
KJA-3 & Kerapu & Pada Insang: & \\
& Cantik & Trichodina & $20 \%$ \\
& & Gill fluke & $40 \%$ \\
& & Benedenia & $10 \%$ \\
& & Pada Kulit: & \\
& & Hirudinea & $100 \%$ \\
\hline
\end{tabular}

Sebetulnya parasit Trichodina tidak mematikan secara langsung bila terdapat dalam jumlah sedikit. Sebaliknya bila terdapat dalam jumlah yang banyak dapat memicu produksi lendir yang berlebihan yang dapat menimbulkan peradangan dan gangguan pernafasan. Pada kondisi budidaya dimana ikan dalam kondisi stress, kandungan bahan organik tinggi, serta kepadatan ikan tinggi, maka parasit ini berkembang dengan cepat melalui cara pembelahan biner. Selain itu gerakannya yang memutar dapat menimbulkan iritasi atau kerusakan pada jaringan inangnya dan dapat menjadi pintu masuk bagi mikro-organisme patogen lain seperti bakteri misalnya untuk menginfeksi ikan. Parasit Trichodina mampu menembus ke dalam lamella insang dan bahkan menembus ke dalam pembulu darah sehingga bisa menyebabkan pendarahan [21].

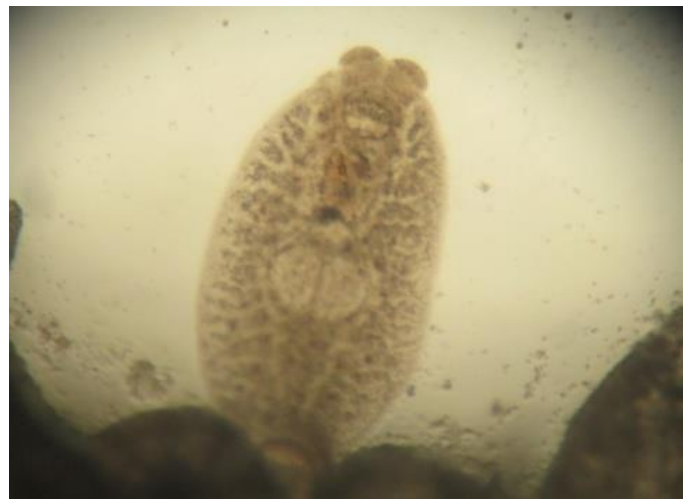

Gambar 4. Parasit Benedenia

Parasit Benedenia (Gambar 4) dikenal juga dengan nama cacing kulit karena biasanya menempel pada bagian kulit ikan dan bisa menimbulkan iritasi kulit sebagai titik masuk infeksi sekunder. Keberadaan parasit ini mudah dideteksi dengan cara merendam ikan dalam air tawar sampai lepas dan warna parasit berubah jadi putih. Ikan laut yang terdeteksi terinfeksi parasit ini adalah cobia, kerapu sunu, kerapu pasir, kerapu macan [13]. Tapi belakangan semua ikan laut budidaya, termasuk kerapu hibrida, juga terinfeksi oleh parasit ini. Tanda yang umum terlihat bila ikan terinfeksi parasit ini antara lain menurunnya nafsu makan, berenang lemah, dan pada tingkat parah dapat menimbulkan luka pada kulit dan membuka peluang terjadinya infeksi sekunder oleh bakteri. Infeksi Benedenia dapat diatasi dengan cara merendam ikan sakit dalam air tawar selama 30-60 menit, tergantung spesies ikan. Ikan-ikan yang hidup di air laut murni biasanya kurang tahan terhadap perendaman dalam air tawar dalam waktu yang lama. Sebaliknya ikan yang hidup di daerah muara dengan salinitas yang cenderung payau bisa direndam lebih lama dalam air tawar sehingga semua parasit bisa terlepas dari tubuh ikan tersebut.

Hasil pemantauan pada bulan Juni menunjukkan bahwa jenis parasit yang menginfeksi ikan terdiri dari cacing insang, Trichodina, Benedenia, Cryptocaryon, dan Hirudinea (Tabel 5). Dari beberapa kali pengamatan diketahui bahwa ikan kakap putih (Lates calcarifer) sangat jarang terinfeksi oleh lintah Hirudinea walaupun dibudidayakan dalam kawasan yang sama dengan ikan 
kerapu. Hal tersebut menunjukkan bahwa ikan kakap putih lebih tahan terhadap infeksi Hirudinea dibanding ikan kerapu.

Tabel 4. Jenis dan prevalensi parasit yang ditemukan

\begin{tabular}{|c|c|c|c|}
\hline KJA & $\begin{array}{c}\text { Ikan } \\
\text { Sampel }\end{array}$ & $\begin{array}{c}\text { Jenis } \\
\text { Parasit }\end{array}$ & Prevalensi \\
\hline KJA-1 & $\begin{array}{l}\text { Kakap } \\
\text { Putih }\end{array}$ & $\begin{array}{l}\text { Pada Insang: } \\
\text { Trichodina } \\
\text { Gill fluke } \\
\text { Benedenia } \\
\text { Pada Kulit: } \\
\text { Benedenia } \\
\text { Trichodina }\end{array}$ & $\begin{array}{c}70 \% \\
100 \% \\
40 \% \\
\\
60 \% \\
20 \%\end{array}$ \\
\hline KJA-2 & $\begin{array}{l}\text { Kerapu } \\
\text { Cantik }\end{array}$ & $\begin{array}{l}\text { Pada Insang: } \\
\text { Trichodina } \\
\text { Pada Kulit: } \\
\text { Benedenia } \\
\text { Hirudinea }\end{array}$ & $\begin{array}{l}20 \% \\
\\
20 \% \\
50 \%\end{array}$ \\
\hline KJA-3 & $\begin{array}{c}\text { Kerapu } \\
\text { Cantang } \\
\text { dan } \\
\text { Cantik }\end{array}$ & $\begin{array}{l}\text { Pada Insang: } \\
\text { Trichodina } \\
\text { Gill fluke } \\
\text { Pada Kulit: } \\
\text { Hirudinea }\end{array}$ & $\begin{array}{l}10 \% \\
20 \%\end{array}$ \\
\hline
\end{tabular}

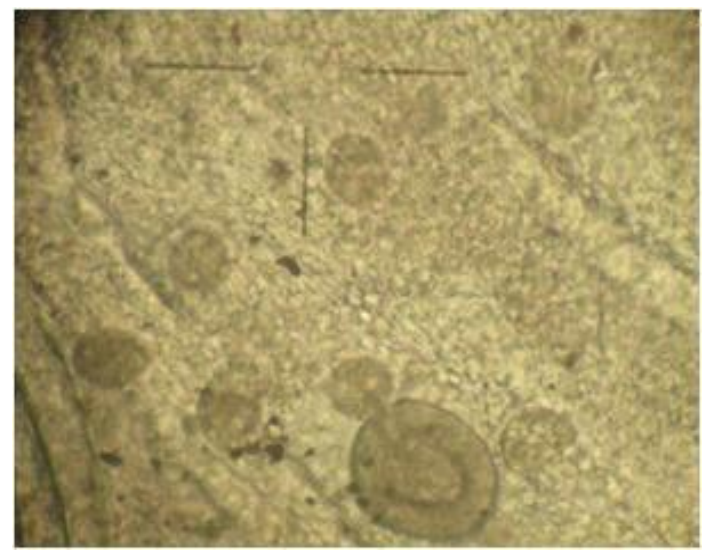

Gambar 5. Cryptocaryon pada kulit ikan

Parasit Cryptocaryon (Gambar 5) sebelumnya sudah dilaporkan menginfeksi berbagai spesies ikan laut yang dibudidayakan termasuk cobia, kerapu sunu, kue, dan bandeng [22]. Infeksi oleh Cryptocaryon dikenal dengan nama Cryptocaryoniosis atau dengan nama lain yaitu "white spot" karena penampakannya pada permukaan tubuh yang ditandai dengan bercak putih. Parasit ini berbahaya karena dapat menyebabkan luka pada bagian tubuh yang diserang seperti insang dan permukaan tubuh. Selain itu parasit ini sulit diberantas karena mempunyai beberapa stadia dalam perkembangannya dan tidak semua stadia-stadia tersebut sensitif terhadap obat/bahan kimia yang umum digunakan dalam pengendalian parasit. Dari empat stadia perkembangannya (kista, theront, trophont, dan tomont) hanya stadia tomont dan theront yang dapat dibunuh dengan bahan kimia. Perendaman ikan yang sakit selama 1 jam dalam formalin $50 \mathrm{ppm}$ dan diulang setiap 3 hari sebanyak 3 kali terbukti efektif mengendalikan infeksi parasit Cryptocaryon irritans [23].

Tabel 5. Jenis dan prevalensi parasit yang ditemukan

\begin{tabular}{|c|c|c|c|}
\hline KJA & $\begin{array}{c}\text { Ikan } \\
\text { Sampel }\end{array}$ & Jenis Parasit & Prevalensi \\
\hline KJA-1 & $\begin{array}{l}\text { Kakap } \\
\text { Putih }\end{array}$ & $\begin{array}{l}\text { Pada Insang: } \\
\text { Gill fluke } \\
\text { Pada Kulit: }\end{array}$ & $\begin{array}{c}40 \% \\
-\end{array}$ \\
\hline KJA-2 & $\begin{array}{l}\text { Kerapu } \\
\text { Cantik }\end{array}$ & $\begin{array}{l}\text { Pada Insang: } \\
\text { Pada Kulit: } \\
\text { Hirudinea }\end{array}$ & $100 \%$ \\
\hline KJA-3 & $\begin{array}{l}\text { Kakap } \\
\text { Putih }\end{array}$ & $\begin{array}{l}\text { Pada Insang: } \\
\text { Trichodina } \\
\text { Gill fluke } \\
\text { Cryptocaryon } \\
\text { Pada Kulit: } \\
\text { Benedenia }\end{array}$ & $\begin{array}{l}20 \% \\
60 \% \\
40 \% \\
60 \%\end{array}$ \\
\hline
\end{tabular}

Dari rekapitulasi data parasit yang menyerang insang ikan budidaya di KJA Teluk Kaping terlihat bahwa hanya cacing insang ( ill fluke) yang selalu terdapat selama 5 bulan pemantauan. Pada urutan kedua yang sering ditemukan adalah parasit Trichodina dan diikuti oleh Benedenia. Parasit Cryptocaryon dan Lepeophtheirus hanya terdeteksi satu kali pada bulan yang berbeda (Tabel 6). Data tersebut menunjukkan bahwa cacing insang (Gambar 6) adalah parasit yang perlu mendapat perhatian khusus dalam pemeliharaan ikan di KJA, khususnya di Teluk Kaping, Gerokgak, Bali.

Keberadaan parasit juga bisa diketahui dari telur yang mereka lepas. Telur parasit cacing insang berbentuk agak lonjong dengan filamen yang panjang. Dengan bantuan filamen ini telur bisa menempel pada substrat yang terdapat di lingkungan budidaya. Setelah 
sekitar 5 hari maka telur akan menetas dan menghasilkan larva parasit (onchomiracidia) yang aktif berenang dengan bantuan cilia mencari inang baru dan menempel pada insang ikan inang menjadi parasit.

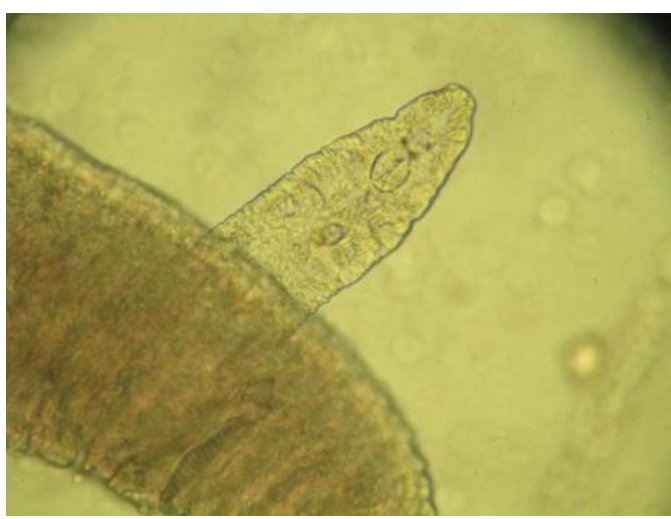

Gambar 6. Cacing insang

Tabel 6. Rata-rata prevalensi (\%) parasit pada insang ikan dari tiga KJA yang diamati di Teluk Kaping, Gerokgak, Bali

\begin{tabular}{lccccc}
\hline \multirow{2}{*}{ Parasit } & \multicolumn{5}{c}{ Bulan } \\
\cline { 2 - 6 } Hirudinea & $\mathbf{2}$ & $\mathbf{3}$ & $\mathbf{4}$ & $\mathbf{5}$ & $\mathbf{6}$ \\
Trichodina sp & 20 & 0 & 6.67 & 33.3 & 6.67 \\
Benedenia sp & 3.33 & 0 & 3.33 & 13.3 & 0 \\
Gill fluke & 10 & 13.3 & 13.3 & 40 & 33.3 \\
$\begin{array}{l}\text { Cryptocaryon } \\
\text { sp }\end{array}$ & 0 & 0 & 0 & 0 & 13.3 \\
$\begin{array}{l}\text { Lepeophtheirus } \\
\text { sp }\end{array}$ & 0 & 26.6 & 0 & 0 & 0 \\
& & & & & \\
\hline
\end{tabular}

Pada Tabel 7 terlihat bahwa parasit Hirudinea dan Benedenia selalu terpantau setiap bulan selama 5 bulan pengamatan. Itu artinya parasit Hirudinea dan Benedenia sudah menjadi musuh abadi bagi para pembudidaya ikan di KJA Teluk Kaping. Parasit Benedenia lebih mudah ditanggulangi dengan cara merendam ikan yang terinfeksi dalam air tawar secara berkala. Sebaliknya untuk parasit Hirudinea pengendaliannya tidak bisa hanya dengan cara perendaman dalam air tawar saja tapi sudah harus secara holistik supaya siklus hidupnya terputus, termasuk dari pihak pemerintah sebagai pengambil kebijakan. Ada indikasi bahwa boomingnya lintah Hirudinea berhubungan dengan memburuknya lingkungan perairan di mana KJA dibangun.

Tabel 7. Rata-rata prevalensi (\%) parasit pada lendir kulit ikan dari tiga KJA di Teluk Kaping, Gerokgak, Bali

\begin{tabular}{lccccc}
\hline \multirow{2}{*}{\multicolumn{1}{c}{ Parasit }} & \multicolumn{5}{c}{ Bulan } \\
\cline { 2 - 6 } & $\mathbf{2}$ & $\mathbf{3}$ & $\mathbf{4}$ & $\mathbf{5}$ & $\mathbf{6}$ \\
\hline Hirudinea & 26.6 & 90 & 100 & 20 & 33.3 \\
Trichodina $\mathbf{s p}$ & 0 & 0 & 0 & 6.67 & 0 \\
Benedenia $\mathbf{~ s p}$ & 40 & 13.3 & 3.3 & 26.6 & 20 \\
Gill fluke & 3.33 & 0 & 0 & 0 & 0 \\
$\begin{array}{l}\text { Cryptocaryon } \\
\text { sp }\end{array}$ & 0 & 0 & 0 & 0 & 0 \\
$\begin{array}{l}\text { Lepeophtheirus } \\
\text { sp }\end{array}$ & 0 & 0 & 0 & 0 & 0 \\
\hline
\end{tabular}

\section{KESIMPULAN}

Berdasarkan hasil penelitian ini dapat disimpulkan bahwa ada enam jenis ektoparasit yang menyerang ikan budidaya di karamba jaring apung di Teluk Kaping, Kecamatan Gerokgak, Buleleng, Bali. Keenam ektoparasit tersebut adalah lintah Hirudinea (Zeylanicobdella arugamensis), Trichodina sp, Benedenia sp, cacing insang (gill fluke), Cryptocaryon sp, dan Lepeophtheirus sp. Dari keenam jenis parasit tersebut, Hirudinea, cacing insang, dan Benedenia selalu terdeteksi selama lima bulan penelitian. Tingkat prevalensi tertinggi dari ketiga parasit ini masing-masing adalah $100 \%, 40 \%$, dan $40 \%$.

\section{DAFTAR PUSTAKA}

[1] Dinas Perikanan dan Kelautan, Kabupaten Buleleng, "Laporan akuntabilitas kinerja instansi pemerintah (LAKIP) tahun 2016, Pemerintah Kabupaten Buleleng", https://bulelengkab.go.id>bankdata.

[2] I. N. Radiarta, Erlania, K. Sugama, H. T. Yudha, dan W. Wada, "Frequent monitoring of water temperature in Pegametan Bay, Bali: a preliminary assessment towards management of marine aquaculture development". Indonesian Aquaculture Journal, vol. 9, no. 2, hal. 185-193, 2014. 
[3] I. N. Radiarta, dan Erlania, "Pemetaan keramba jaring apung ikan laut di Teluk Pegametan dan Teluk Penerusan Kabupaten Buleleng, Bali”, dalam Prosiding Forum Inovasi Teknologi Akuakultur, hal. 675-682, 2015.

[4] L. Landesman, "Negative impacts of coastal aquaculture development.World", Aquaculture, vol. 25, hal. 12-17, 1994.

[5] L. D. Lacierda, A. G. Vaisman, L. P. Maia, C. A. R Silva, dan E. M. S. Cunha, "Relative importance of nitrogen and phosphorus emissions from shrimp farming and other anthropogenic sources for six estuaries along the NE Brazilian coast", Aquaculture, vol. 253, hal. 433446, 2006.

[6] C. E. Boyd, "Guidelines for aquaculture effluent management at the farm-level", Aquaculture, vol. 226 no. 1-4, hal. 101112, 2003.

[7] S. D. Costanzo, M. J. Donohue, dan W. C. Dennison, "Assessing the influence and distribution of shrimp pond effluent in a tidal mangrove creek in north-east Australia", Marine Pollution Bulletin, vol. 48, hal. 514-525, 2004.

[8] T. M. Samocha, I. M. Lopez, E. R. Jones, S. Jackson, dan A. L. Lawrence, "Characterization of intake and effluent waters from intensive and semiintensive shrimp farms in Texas", Aquaculture Research, vol. 35, hal. 321-339, 2004.

[9] K. Mahardika, I. Mastuti, Sudewi, dan Zafran, "Identification and life cycle of marine leech isolated from cultured hybrid grouper in the Northern Bali waters of Indonesia" Indonesian Aquaculture Journal, vol. 13, no. 1, hal. 41-49, 2018.

[10] M.Chandra, "Zeylanicobdella arugamensis", Rec.Zool.Surv. India, vol 80, hal. 268-273, 1983.
[11] Z. Kabata, "Parasites and diseases of fish cultured in the tropics", Taylor \& Francis, London \& Philadelphia, 518 p., 1985.

[12] J. Grabda, "Marine Fish Parasitology: An Outline", Polish Scientific Publication", Warszawa, 306 p, 1991.

[13] Zafran, D. Roza, I. Koesharyani, F. Johnny, dan K. Yuasa, "Manual for Fish Diseases Diagnosis: Marine fish and crustacean diseases in Indonesia". Gondol Research Station for Coastal Fisheries and Japan International Cooperation Agency, 44 p, 1998.

[14] I. Koesharyani, D. Roza, K. Mahardika, F. Johnny, Zafran, dan K.Yuasa, "Manual for Fish Diseases Diagnosis-II, Marine fish and crustacean diseases in Indonesia", Sugama, K., Ikenoue, H., \& Kawahara, S. (eds), Gondol Marine Research for Mariculture, Central Research Institute for Sea Exploration and Fisheries, Department of Marine Affair and Fisheries, and Japan International Cooperation Agency, 49 p., 2001.

[15] Murwantoko, S. L. C. Negoro, A. Isnansetyo, dan Zafran, "Life cycle of marine leech (Zeylanicobdella arugamensis) from cultured cantik hybrid grouper (Epinephelus sp) and their susceptibility against chemicals", Aquacultura Indonesiana, vol. 18, no. 2, hal. 72-76, 2017.

[16] T. S. Leong, dan S. Y. Wong, "A comparative study of the parasite fauna of wild and cultured grouper (Epinephelus malabaricus Bloch et Schneider) in Malaysia", Aquaculture, vol. 68, p. 203-207, 1988.

[17] E. R. Cruz-Lacierda, J. D. Toledo, J. D. Tan-Fermin, dan E. M. Burreson, "Marine leech (Zeylanicobdella arugamensis) infestation on cultured orange-spotted grouper, Epinephelus 
coioides", Aquaculture, vol. 185, hal. 191-196, 2000.

[18] Kua, B. C., M. A. Azmi, dan N. K. A. Hamid, "Live cycle of the marine leech (Zeylanicobdella arugamensis) isolated from sea bass (Lates cacarifer) under laboratory condition", Aquaculture, vol. 302, p. 153-157, 2010.

[19] L. T. Seng, Z. Tan, dan W. J. Enright, "Important parasitic diseases in cultured marine fish in the Asia-Pacific region: Part 2-Control measures", Aquaculture Asia Pacific, vol. 2, no. 2, hal. 25-27, 2006.

[20] E. R. Cruz-Lacierda, dan G. E. ErazoPagador, "Parasitic diseases", In Diseases of Cultured Groupers. K. Nagasawa \& E.R. Cruz-Lacierda (Eds.),
SEAFDEC-AQD, Iloilo, Philippines. hal. $33-57,2004$

[21] A. Hilal, dan Sriwulan, "Infeksi parasit pada ikan-ikan air tawar budidaya di Sulawesi Selatan", Dalam Prosiding Konferensi Nasional Akuakultur 2005, MAI. hal. 115-121, 2006.

[22] Zafran, "Penyakit parasitik pada budidaya ikan laut di daerah Bali", Prosiding Seminar Nasional Kelautan V. Universitas Hang Tuah, Surabaya 23 April 2009: hal. II-3136, 2009.

[23] Zafran, "Infeksi Cryptocaryon irritans pada benih kerapu cantik dan penanggulangannya", Dalam Prosiding Pertemuan Ilmiah Tahunan XIII ISOI 2016, Surabaya, hal. 189-194, 2017. 